\title{
PENGARUH BENTUK STRUKTUR KEPEMILIKAN TERHADAP KEBIJAKAN HUTANG (Studi Empiris Pada Perusahaan di BEJ)
}

\author{
Jati Imantoro \\ e-mail:jatiimantoro@yahoo.com
}

Dosen Tetap FE Universitas Muhammadiyah Metro

\begin{abstract}
ABSTRAK
Penelitian ini bertujuan untuk mengetahui pengaruh bentuk struktur kepemilikan yang terdiri dari Insider Ownership, Institutional Investor, dan Shareholder Dispertions terhadap kebijakan hutang perusahan-perusahaan di Indonesia

Sampel yang digunakan dalam penelitian ini adalah 90 perusahaan yang terdaftar di BEJ untuk periode tahun 2004 sampai dengan 2006. Pemilihan sampel dengan menggunakan metode purposive sampling, yaitu dengan mendasarkan pada criteria-kriteria tertentu. Data yang diperoleh dianalisis dengan menggunakan metode regresi berganda untuk menguji pengaruh struktur kepemilikan terhadap kebijakan hutang.

Dalam penelitian ini diketemukan bukti secara empiris tidak seluruh bentuk struktur kepemilikan yaitu: Insider Ownership, Institutional Investor, dan Shareholder Dispersion mempengaruhi kebijakan hutang yang dilakukan oleh perusahaan-perusahaan di Indonesia. Kemungkinan dikarenakan penelitian ini hanya mempertimbangkan prosentase kepemilikan saham saja, seharusnya dalam penelitian juga memperimbangkan factor internal diri manajer sebagai pihak pengambil keputusan. Seperti: seberapa besar manajer mau untuk bertanggung jawab terhadap resiko atas keputusan yang ia ambil (risk beating), tingkat loyalitas manajer terhadap perusahaan yang ia pimpin.
\end{abstract}

Kata Kunci: Insider Ownersip, Institutional Investor, Shareholder Dispertion, dan Kebijakan Hutang

\section{PENDAHULUAN}

\subsection{Latar Belakang Masalah}

Dalam pelaksanaan pengembangan perusahaan, maka perusahaan tidak terlepas dengan masalah pendanaan atau modal. Usaha-usaha pengadaan dana atau modal perusahaan memiliki dua alternative, alternative pertama yaitu pengadaan dana yang berasal dari dalam perusahaan dapat berupa laba, laba ditahan, cadangan peyusutan aktiva tetap. Sedangkan alternative kedua adalah dengan pengadaan dana yang berasal dari luar yaitu dapat dilakukan dengan menerbitkan hutang dan menerbitkan saham.

Dalam kaitannya pendanaan perusahaan bersumber dari hutang ini memunculkan permasalahn agensi antara manajer sebagai pihak pengambil keputusan dengan pemilik saham. Menurut teori agensi yang dikembangkan Jensen dan Meckling (1976) manejer sebagai pihak pengambil keputusan perusahaan, dimana manajer merupakan pihak yang diberikan kepercayaan oleh pemegang saham dianggap tidak selalu bertindak sesuai dengan kepentingan pemengan saham. Oleh karena itu, perlu ada mekanisme agar manajer mau bertindak sesuai dengan kepentingan pemegang saham. Salah satu mekanisme yang diusulkan oleh Jensen dan Meckling (1967) adalah dengan menambah porsi hutang. Menambah hutang dapat mengurangi masalah agensi karena dua alasan. Pertama, dengan meningkatkan hutang maka akan semakin kecil porsi saham yang harus dijual oleh 
perusahaan. Semakin kecil saham yang beredar maka akan semakin kecil masalah agensi antara pihak manajer dengan pemegang saham, kedua, semakin besar hutang perusahaan maka akan semakin kecil dana "mengangur" (free cash flow) yang dapat dipakai manajer untuk keperluan-keperluan yang kurang perlu. Semakin besar hutang maka perusahaan harus mencadangkan lebih banyak kas untuk membayar bunga hutang dan untuk mengangsur pojok pinjaman. Mekanisme untuk mengurangi free cash flow ini oleh Jensen (1986) dikelompokkan dengan mekanisme bonding, yaitu suatu mekanisme yang digunakan oleh manajer untuk membuktikan bahwa mereka tidak menghamburkan dana perusahaan dan mereka berani mengambil resiko kehilangan perusahaan jika mereka tidak bias mengelola perusahaan dengan baik.

Penambahan porsi hutang perusahaan jika diyakini dapat mengurangi konflik agensi antara manajer dengan pemegang perusahan, pertanyaan yang muncul mengapa perusahaan tidak sekalian menggunakan hutang yang sebesar-besarnya (meskipun porsinya tidak $100 \%$ )? Jawabanya adalah ternyata penambahan hutang dapat menciptakan permasalahan agensi pada hutang. Ketika porsi hutang dalam struktur modal perusahaan meningkat maka resiko financial yang ditanggung bondholder (pemberi hutang) meningkat sementara manajer dan shareholder (pemegang saham) tetap menjadi pengendali keputusan yang diambil perusahaan. Kondisi ini membuka peluang bagi manajer dan pemegang saham untuk memanfaatkan kekayaan bondholder untuk kepentingan manajer dan pemegang saham. Untuk meminimumkan konflik kepentingan antara pihak-pihak terkait, maka diperlukan mekanisme pengawasan yang dapat mensejajarkan kepentingan antar pihak-pihak yang terkait. Namun mekanisme pengawasan ini akan menimbukan biaya yang disebut agency cost.

Dalam penelitian yang dilakukan oleh Mohd (1988) dalam Wuryaningsih (2002) senada dengan pendapat Jensen dan Meckling (1976) bahwa peningkatan kepemilikan manajer (insider ownership) dalam struktur kepemilikan perusahaan dapat menekan manajer untuk tidak mengambil keputusan yang hanya mementingkan kepentingannya saja. Menurut pendekatan ini agency problem dapat dikurangi bila manajer memiliki kepemilikan saham dalam perusahaan. Pendakatan lain yang dapat digunakan untuk mengurangi agency problem adalah dengan meningkatkan kepemilikan saham dari luar perusahaan yaitu institutional investor dan shareholder dispertion yang secara tidak langsung kedua pendekatan di atas akan membatasi manajer dan pemegang saham perusahaan dalam menggunakan hutang untuk kegiatan "konsumtif" yang kurang perlu untuk dilakukan. Sehingga, secara otomatis akan mengurangi kebijakan hutang yang dilakukan oleh perusahaan.

\subsection{Rumusan Masalah}

Berdasarkan latar belakang yang telah diuraikan di atas maka peneliti merumuskan masalah sebagai berikut: Apakah Insider Ownership, Institutional Investor, dan Shareholder Dispersion memiliki pengaruh yang parsial terhadap kebijakan hutang yang dilakukan oleh perusahaan-perusahaan di Indonesia.

\section{KERANGKA PIKIR DAN PENGEMBANGAN HIPOTESIS}

\subsection{Pengaruh Insider Ownership terhadap Kebijakan Hutang}

Hasil penelitian Friend dan Hasbrouk (1988) senada dengan pendapat Jensen dan Meckling (1976) bahwa peningkatan kepemilikan manajer (insider ownership) memiliki hubungan negative dengan kebijakan hutang. Dalam arti bahwa jika semakin tinggi kepemilikan manajer dalam struktur kepemilikan perusahaan maka penggunaan hutang oleh perusahaan semakin rendah. Meningkatnya kepemilikan manajer akan menyebabkan manajer akan semakin hati-hati dalam menggunakan hutang dan menghindari prilaku oportunistik, 
karena mereka ikut menanggung konsekuensi dari keputusan yang diambilnya, sehingga perusahaan memiliki hutang yang rendah. Hal ini bisa mengontrol konflik keagenan dan mengurangi biaya agency (agency cost) dalam rangka monitoring.

Tetapi dalam penelitan lain yang dilakukan oleh Kim dan Sorenson (1986), menemukan adanya hubungan positif antara kebijakan hutang dengan insider ownership. Dengan alasan hubungan ini dipelajari dari demain and supply hypothesis. Pendekatan hipotesis ini menjelaskan bahwa perusahaan yang dikuasai oleh insider atau perusahaan tertutup memiliki debt agency cost yang rendah sehingga cenderung menggunakkan hutang yang besar dalam pendanaannya. Dari uraian di atas dapat dirumuskan hipotesis pertama:

$H_{1}$ : Kepemilikan internal (insider ownership) mempunyai pengaruh negative terhadap kebijakan hutang Perusahaan

\subsection{Pengaruh Institutional Investor Terhadap Kebijakan Hutang}

Shleifer dan Vishny (1986) menyatakan bahwa pemegang saham besar (large shareholder) mempunyai arti penting dalam memonitor prilaku manajer dalam perusahaan. Menurut hasil penelitian mereka adanya konsetrasi kepemilikan dalam perusahaan, maka pemegang saham besar seperti institutional investor dapat memonitor tim manajemen secara lebih efektif . meningkatnya kepemilikan oleh institutional investor juga dapat mengimbangi kebutuhan terhadap penggunaan hutang oleh perusahaan. Semakin tinggi kepemilikan saham institutional maka diharapkan akan semakin kuat kontrol internal terhadap perusahaan, sehingga dapat mengurangi biaya keagenan, serta mengurangi penggunaan hutang oleh perusahaan. Berdasarkan uraian di atas dapat dirumuskan hipotesis kedua:

$\mathrm{H}_{2}$ : Kepemilikan Institutional Investor memiliki pengaruh negatif terhadap kebijakan hutang perusahaan

\subsection{Pengaruh Shareholder Dispersion Terhadap Kebijakan Hutang}

Menurut Jensen dan Meckling (1976) menyatakan bahwa jika jumlah pemegang saham semakin menyebar, maka konsentrasi kepemilikan akan terpecah dan menyebar, dan kondisi ini akan meyebabkan hubungan yang negative terhadap debt ratio. Hal ini didukung oleh pernyataan Esterbrook (1984), bahwa pemegang saham yang menyebar (diffused shareholder) memiliki pengaruh terhadap posisi manajer yang konservatif dalam penggunaan hutang. Dari uraian di atas dapat dirumuskan hypothesis yang ketiga:

H3: Shareholder Dispersion mempunyai pengaruh yang negative terhadap kebijakan hutang perusahaan

\section{KAJIAN PUSTAKA}

$2.1 \quad$ Landasan Teori

\subsubsection{Teori Agensi}

Hubungan agency merupakan kontrak, baik bersifat eksplisit maupun implisit, di mana satu atau lebih orang (yang disebut principal) meminta orang lain (yang disebut dengan agen) untuk mengambil tindakan atas nama principal. Dalam kontrak tersebut terdapat pendelegasian wewenang untuk pengambilan keputusan kepada agen. Dalam konteks perusahaan, principal adalah pemilik perusahaan (pemegang saham) dan agennya adalah manajer. Manajer diberikan wewenang untuk mengambil keputusan yang berkaitan dengan oprasional dan strategi perusahaan dengan harapan keputusan-keputusan yang akan diambil akan memaksimalkan nilai perusahaan. 
Harapan agar manajer selalu mengambil keputusan yang sejalan dengan peningkatan nilai perusahaan seringkali tidak terwujud. Banyak keputusan yang diambil oleh manajer yang justru lebih menguntungkan manajer dan mengesampingkan kepentingan pemegang saham. Penggunaan dana perusahaan untuk pembelian fasilitas manajer yang berlebihan, penahanan laba perusahaan untuk investasi yang kurang menguntungkan, dan berbagai kecurangan yang dapat mengurangi laba atau asset perusahaan seperti menjual produk dengan harga murah ke perusahaan lain yang ternyata perusahaan milik manajer adalah beberapa praktik yang bertententangan dengan kepentingan pemegang saham.

Mengapa manajer memiliki kesempatan untuk melakukan tindakan yang bertententangan dengan kepentingan pemegang saham? Jensen dan meckling (1976) dalam Hidayat (2004), menyatakan bahwa masalah keagenan akan potensial terjadi apabila proporsi kepemilikan manajer (insider) atas perusahaan kurang dari 100\%. Sehingga manajer cenderung bertindak untuk mengejar kepentingan dirinya dan bukan berdasarkan memaksimalkan nilai dalam pengambila keputusan dalam pendanaan perusahaan. Selain itu, Jensen dan Meckling (1976) dalam Hidayat (2004) menyatakan bahwa kondisi yang demikian merupakan konsekuensi dari pemisahan fungsi pengelolaan dan fungsi kepemilikan atau sering disebut sparation of dicision making and risk beating function of the firm. Pengambil keputusan yaitu, yaitu pihak manajemen relative tidak menaggung resiko atas kesalahan dalam pengambilan keputusan, resiko kesalahan tersebut sepenuhnya ditanggung oleh principal (pemilk saham).

Kesimpulannya, menurut teori keagenan para manajer cenderung bertindak untuk mengejar kepentingan mereka sendiri, bukan berdasarkan maksimalisasi nilai perusahaan dalam keputusan pendanaan (Jensen dan Meckling (1967) dalam Wuryaningsih (2004)). Pendapat lain didasarkan pada asumsi bahwa para manajer yang bertanggung jawab pada keputusan keuangan tidak mampu untuk melakukan diversifikasi dalam human capital.

\subsubsection{Alternatif Untuk Mengurangi Konflik Keagenan dan Agency Cost}

Jensen dan Meckling (1976) mengidentifikasi ada dua cara untuk mengurangi kesempatan manajer melakukan tindakan yang merugika investor, yaitu: (1) Investor luar melakukan pengawasan (monitoring), dan (2) Manajer sendiri melakukan pembatasan atas tindakannya (bonding).

\subsubsection{Mekanisme Kontrol Dengan Monitoring}

Ada beberapa mekanisme monitoring untuk mengurangi konflik keagenan dan. Beberapa mekanisme-mekanisme control yang dapat dipakai untuk mengurangi konflik keagenan:

a. Pembentukan Dewan Komisaris

Pembentukan dewan komisaris adalah salah satu mekanisme yang banyak dipakai oleh perusahaan untuk memonitoring kinerja manajer. Namun menurut beberapa penelitian pengawasan oleh komisaris terhadap manajer kurang berjalan efektif, ini terjadi dikarenakan pemilihan dewan komisaris kurang demokratis dan setelah terpilih tidak berani untuk memberikan kritik terhadap manajemen.

b. Pasar Corporate Control

Mane (1965) pasar corporate control atau istilah lainnya takeover (pengambilalihan perusahaan) dilakukan perusahaan yang menurun nilainya akibat adanya masalah agensi oleh perusahaan lain, merupakan mekanisme yang lebih bagus sehingga masalah agensi dapat dikurangi.

c. Pemegang Saham Besar 
Mekanisme yang banyak dipakai untuk mengawasi manajemen adalah melalui pemegang saham besar (large outside shareholder) yang biasanya merupakan lembaga investmen banking, perusahaan asuransi, perusahaan dana pension, perusahaan resakdana, dan bank.

d. Kepemilikan Terkonsentrasi

Mekanisme pengurangan masalah agensi yang agak mirip dengan mekanisme pemegang saham besar adalah mekanisme lewat kepemilikan yang lebih terkonsentrasi. Tetapi, disbanding dengan mekanisme pemegang saham besar, kepemilikan saham terkonsentrasi memiliki kekuatan control yang lebih rendah karena mereka tetap harus melakukan koordinasi untuk menjalankan hak kontrolnya.

e. Pasar Manajer

Fama (1980) menyatakan bahwa masalah agensi akan sangat berkurang dengan sendirinya karena manajer akan dicatat kinerjanya oleh pasar manajer baik yang ada dalam perusahaan maupun yang berasal dari luar perusahaan.

\subsubsection{Mekanisme Kontrol Dengan Peningkatan Kepemilikan Manajer}

Teori kepemilikan yang dikemukakan oleh Jensen dan Meckling (1976) mengisyaratkan bahwa ada hubungan positif antara kepemilikan manajerial dengan nilai perusahaan.

\subsubsection{Mekanisme Kontrol dengan Bonding}

Jensen (1986) melihat masalah keagenan dari sudut ketersediaan uang yang menganggur (free cash flow) yang dapat digunakan manajer dalam kegiatan konsumtif untuk memenuhi kepentingannya. Free cash flows tersebut berasal dari kelebihan dana yang ada dalam perusahaan setelah seluruh proyek investasi yang menghasilkan net present value positif dilaksanakan. Sehingga apabila masalah keagenan ingin dikurangi maka free cash flow tersebut harus dikurangi terlebih dahulu, upaya yang dapat dilakukan oleh manajer adalah dengan menahan diri (bonding) untuk tidak menggunakan free cash flows untuk menciptakan penyimpangan-penyimpangan, yaitu dengan cara dengan memperkecil free cash flows itu sendiri. Cara bonding yang disarankan oleh Jensen (1986) di atas adalah dengan car meningkatkan jumlah hutang perusahaan. Dengan semakin besar hutang yang dimiliki perusahaan maka akan semakin banyak dana yang harus digunakan perusahaan untuk membayar angsuran dan bunga hutang itu sendiri.

\subsection{Penelitian Terdahulu}

Penelitan yang meneliti bagaimanakah pengaruh struktur kepemilikan terhadap kebijakan hutang di Indonesia telah banyak dilakukan di Indonesia. Di ataranya penelitian yang dilakukan oleh hidayat (2004) meneliti bagaimanakah pengaruh struktur kepemilikan, factor internal perusahaan, factor internal peusahaan terhadap kebijakan hutang (debt ratio). Dalam penelitian ini diketemukan hasil bahwa tidak seluruh variable struktur kepemilikan, diataranya insider ownership, institutional investor, dan shareholder dispersion memiliki pengaruh siknifikan pada debt ratio. Hanya variable shareholder dispersion saja yang memiliki pengaruh negative siknifikan pada debt ratio, tetapi variable yang lain tetap memiliki pengaruh negative pada debt ratio.

Penelitian yang dilakukan Wuryaningsih (2002), yang meneliti pengaruh struktur kepemilikan terhadap kebijakan hutang pada perusahaan manufaktur, menghasilkan kesimpulan yang sama bahwa bahwa tidak seluruh variable struktur kepemilikan, diataranya insider ownership, institutional investor, dan shareholder dispersion memiliki pengaruh siknifikan pada debt ratio. Hanya variable shareholder dispersion saja yang memiliki pengaruh negative siknifikan pada debt ratio, tetapi variable yang lain tetap memiliki pengaruh negative pada debt ratio. 
Dari penelitian di atas peneliti ingin meneliti kembali bagaimanakah pengaruh struktur kepemilikan terhadap kebijakan hutang, dengan menggunakan sampel seluruh perusahaan yang terdaftar di BEJ, kecuali perusahaan bank dan keuangan. Dan data yang digunakan adalah data time series laporan keuangan perusahaan dari tahun 2004 sampai dengan tahun 2007, yang peneliti yakini data laporan keuangan masuk dalam periode laporan keuangan yang jauh dari pengaruh krisis ekonomi yang terjadi pada era-1998 yang banyak berpengaruh pada kinerja keuangan perusahaan di Indonesia.

\section{METODE PENELITIAN}

\subsection{Populasi dan Sampel}

Penelitian ini menggunakan populasi semua perusahaan yang terdaftar di Bursa Efek Jakarta (BEJ) selama tahun 2004 sampai dengan tahun 2007. Pemilihan sampel dilakukan dengan metode purposive sampling, yaitu dengan berdasarkan criteria tertentu:

a. Perusahaan adalah perusahaan yang terdaftar di BEJ, kecuali perusahaan keuangan dan perbankan.

b. Perusahaan melaporkan laporan keuangan dan dipublikasikan untuk periode 2004 sampai dengan 2008.

c. Laporan perusahaan memiliki kelengkapan data yang dibutuhkan penelitian seperti data insider ownership, institutiona linvestor, total hutang jangka panjang, dan total equity.

d. Memiliki kebijakan hutang dan EBIT yang positif.

Dari hasil pemilihan sampel denga criteria di atas dihasilkan sampel perusahaan sebagai berikut:

\begin{tabular}{|l|c|c|c|c|c|c|}
\hline \multicolumn{1}{|c|}{ Tahun } & 2004 & 2005 & 2006 & 2007 & 2008 & Total \\
\hline Populasi & 182 & 182 & 182 & 182 & 187 & 915 \\
Yang dikeluarkan dari sampel karena: & & & & & & \\
1) Tidak melaporkan laporan keuangan & $(0)$ & $(0)$ & $(0)$ & $(0)$ & $(0)$ & $(0)$ \\
2) Tidak Lengkap datanya & $(126)$ & $(120)$ & $(117)$ & $(125)$ & $(123)$ & $(611)$ \\
3) Yang EBIT negatif & $(41)$ & $(42)$ & $(49)$ & $(39)$ & $(43)$ & $(214)$ \\
\hline Sampel yang dipakai & 15 & 20 & 16 & 18 & 21 & 90 \\
\hline
\end{tabular}

\subsection{Variabel Penelitian}

Variable dependen dalam penelitian ini adalah kebijakan hutang yang didasarkan atas nilai debt ratio. Debt ratio merupakan hasil bagi antara hutang jangka panjang tahunan perusahan dengan hutang jangka panjang ditambah dengan shareholder equity tahunan.

Sedangkan variable independen dalam penelitian ini adalah struktur kepemilikan saham perusahaan yang dikelompokkan dalam 2 kelompok besar, yaitu pertama porsi saham yang dimiliki oleh manajer dan komisaris (insider ownership). Kedua porsi saham yang dimiliki pihak luar outside shareholder (institutional investor dan shareholder dispersion).

\subsection{Teknik Analisis}

Teknik analisis penelitian ini menggunakan bantuan program statistic SPSS. Pengujian terhadap hipotesis digunakan dengan model regresi berganda yang bebas dari pelanggaran asumsi klasik. Interprestasi hasil penelitian parsial (uji t) hanya dilakukan terhadap variable independen yang secara statistic mempunyai pengaruh yang siknifikan terhadap variable dependen.

\section{HASIL PENELITIAN DAN PEMBAHASAN \\ 4.1 Uji Normalitas}


Uji normalitas data menggunakan uji kolmogorov-smirnov, dari table one-sample kolmogorov-smirnov tes diketahui nilai asyim.sig. (2tailed) dari seluruh variable yang digunakan nilainya diatas $>0.05$ yang menandakan seluruh variable yang digunakan berdistribusi normal.

One-Sample Kormogorov-Smirnov Test

\begin{tabular}{|c|c|c|c|c|c|}
\hline & & DR & INSDR & INST & SDP \\
\hline $\mathrm{N}$ & & 90 & 90 & 90 & 90 \\
\hline \multirow[t]{2}{*}{ Normal Parameters } & Mean & .2758 & -3.4116 & .5326 & 5.4325 \\
\hline & Std. & .2402 & 4.5313 & .1229 & 1.4303 \\
\hline Deviation & & .126 & .118 & .141 & .118 \\
\hline Most Extrems & Absolute & .124 & .078 & .075 & .118 \\
\hline \multirow[t]{2}{*}{ Differences } & Positive & -.126 & -.118 & -.141 & -.093 \\
\hline & Negative & 1.191 & 1.121 & 1.341 & 1.118 \\
\hline $\begin{array}{l}\text { Kormogorov-Smirnov } \\
\text { Asymp.Siq. (2-tailed) }\end{array}$ & & .117 & .162 & 0.055 & .164 \\
\hline
\end{tabular}

a. Test distribution is Normal

b. Calculaited from data

\subsection{Uji Asumsi Klasik}

4.2.1 Uji Multikolinieritas

Uji Multikolinieritas dilakukan untuk menguji apakah ada hubungan yang kuat antara variable independen di dalam persaman regresi, untuk melihatnya dapat dengan melihat nilai tolerance (TOL), variance in factor (VIF) dan persion correlation matrik. Dengan melihat hasil uji pada nilai persion correlation dalam table di bawah, antara variable independen dimana nilainya tidak melebihi nilai 0.8 ini menunjukkan bahwa tidak terdapat multikolinieritas dalam model regresi yang digunakan.

\section{correlations}

\begin{tabular}{|lc|r|r|r|r|}
\hline & & \multicolumn{1}{c|}{ DR } & \multicolumn{1}{c|}{ INSDR } & \multicolumn{1}{c|}{ ISNT } & \multicolumn{1}{c|}{ SDP } \\
\hline Person Correlation & DR & 1.000 & .444 & -.185 & .273 \\
DR & INS & .444 & 1.000 & -.227 & .362 \\
& & -.185 & -.227 & 1.000 & -162 \\
& INST & .273 & .362 & -.163 & 1.000 \\
\hline Sig. (1-tailed) & SDP & & & & \\
DR & DR & & .000 & .040 & .005 \\
& INS & .000 & .040 & .016 & .000 \\
& & .040 & .016 & .062 & .062 \\
\hline N & INST & .005 & .000 & .062 & \\
& SDP & & & &. \\
DR & DR & 90 & 90 & 90 & 90 \\
& INS & 90 & 90 & 90 & 90 \\
& & 90 & 90 & 90 & 90 \\
& INST & 90 & 90 & 90 & 90 \\
\hline
\end{tabular}

\subsubsection{Uji Autokorelasi}

Uji Autokorelasi untuk menguji apakah model regresi yang digunakan baik maka harus bebas dari autokorelasi, yaitu tidak adanya korelasi antar residual satu observasi dengan observasi yang lain. Untuk melihat apakah tidak terjadi autokorelasi digunakan uji DurbinWatson dari program SPSS. Jika nilai Durbin-Watson mendekati 2 maka tidak terjadi autokorelasi, tetapi jika nilai Durbin-Watson nilainya 0 atau 4 maka terjadi autokorelasi. Dari output uji Durbin-Watson diketahui nilai Durbin-Watson 1,650 maka tidak terjadi autokorelasi 


\section{Uji Durbin Watson}

Model Summaryb

\begin{tabular}{|l|r|r|r|r|c|}
\hline Model & R & R Square & $\begin{array}{c}\text { Adjusted } \\
\text { R Square }\end{array}$ & $\begin{array}{c}\text { Std. Error of } \\
\text { The Estimate }\end{array}$ & $\begin{array}{c}\text { Durbin- } \\
\text { Watson }\end{array}$ \\
\hline 1 & $.466^{\mathrm{a}}$ & .217 & .190 & .2162 & 1.650 \\
\hline
\end{tabular}

a. Predictators: (Constant), SDP, INST,INSDR

b. Dependent Variabele: DR

\subsubsection{Uji Heteroskedastisitas}

Heteroskedastisitas merupakan fenomena dimana nilai dependen tertentu yang dipilih atau ditetapkan masing-masing kesalahan mempunyai varian yang sama (homoskedastisitas) yaitu besaran $\sigma^{2}$. Dalam uji heteroskendastisitas ini digunakan korelasi peringkat Spearman's Rho dengan menggunakan standar residual kurang dari 0,5 maka tidak terjadi heteroskendastisitas. Dari pengujian yang dilakukan dengan Spearman's Rho pada table di bawah koeficien korelasi kurang dari 0,5, dengan demikian tidak terjadi heteroskendastisitas dalam model regresi yang digunakan.

\section{Correlations}

\begin{tabular}{|lll|r|r|r|}
\hline & & INSDR & \multicolumn{1}{c|}{ INST } & \multicolumn{1}{c|}{ SDP } \\
\hline Spearman's rho & INSDR & Correlation Coefficient & 1.000 & $-.278^{* *}$ & $.498^{* *}$ \\
& & & .008 & .000 \\
& Sig. (2-tailed) &. & .00 & 90 & 90 \\
\cline { 2 - 5 } & $\mathrm{N}$ & $-.278^{* *}$ & 1.000 & $-.303^{* *}$ \\
\cline { 2 - 6 } & INST & Correlation Coefficient & .008 &. & .004 \\
& Sig. (2-tailed) & 90 & 90 & 90 \\
\cline { 2 - 6 } & $\mathrm{N}$ & $.498^{* *}$ & $-.303^{* *}$ & 1.000 \\
& SDP & .000 & .004 &. \\
& Correlation Coefficient & 90 & 90 & 90 \\
\hline
\end{tabular}

**. Correlation is significant at the .01 (2-tailed)

\subsection{Pembahasan Pengaruh bentuk Struktur Kepemilikan terhadap Kebijakan Hutang Secara Parsial (Uji t)}

\section{Coefficients}

\begin{tabular}{|c|c|c|c|c|c|c|c|}
\hline \multirow[b]{2}{*}{ Model } & \multicolumn{2}{|c|}{$\begin{array}{l}\text { Unstandardized } \\
\text { Coefficients }\end{array}$} & \multirow{2}{*}{$\begin{array}{c}\text { Standardized } \\
\text { Coefficients } \\
\text { Beta } \\
\end{array}$} & \multirow[b]{2}{*}{$\mathrm{t}$} & \multirow[b]{2}{*}{ Sig. } & \multicolumn{2}{|c|}{$\begin{array}{c}\text { Coliniearity } \\
\text { Statistics }\end{array}$} \\
\hline & B & Std. Error & & & & Tolerance & VIF \\
\hline 1 (Constant) & .451 & .161 & & $\begin{array}{r}2.79 \\
4\end{array}$ & $\begin{array}{r}00 \\
6\end{array}$ & & \\
\hline $\begin{array}{l}\text { INSDR } \\
\text { INST }\end{array}$ & $\begin{array}{r}6.990 \mathrm{E}-02 \\
-.154\end{array}$ & $\begin{array}{l}.016 \\
.192\end{array}$ & $\begin{array}{r}.382 \\
-.079\end{array}$ & $\begin{array}{r}3.66 \\
9 \\
-.799\end{array}$ & $\begin{array}{r}00 \\
0\end{array}$ & $\begin{array}{l}.840 \\
.941\end{array}$ & $\begin{array}{r}1.19 \\
1 \\
1.06\end{array}$ \\
\hline
\end{tabular}




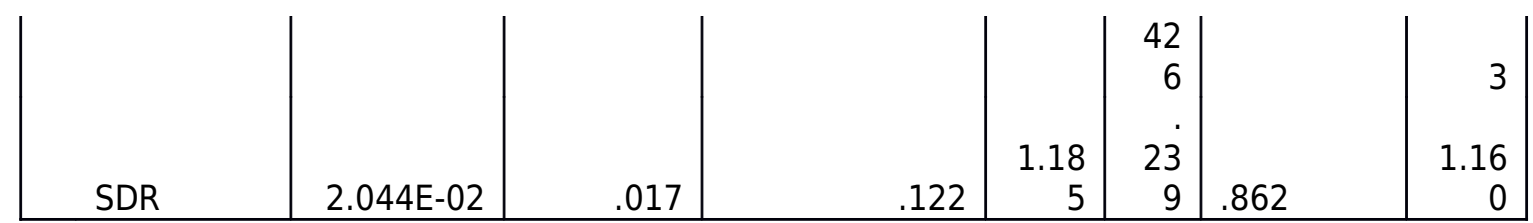

a. Dependent Variable: DR

\subsubsection{Pengaruh Insider Ownership Terhadap Kebijakan Hutang (Hipotesis 1)}

Dari hasil pengujian dengan SPSS secara parsial sebagaimana dalam table uji t di atas nilai signifikansi variable Insider Ownership (INSDR) terhadap kebijakan Hutang (DR) sebesar 0.000 lebih kecil dari nilai $\alpha=5 \%$ maka Hipotesis 1 diterima. Sehingga dapat disimpulkan variable insider ownership berpengaruh siknifikan terhadap kebijakan hutang perusahaan di Indonesia.

Hasil penelitian ini sesuai dan konsisten dengan penelitian yang dilakukan oleh KIM dan Sorenson (1986), bahwa variable insider ownership memiliki pengaruh yang positif terhadap kebijakan hutang perusahaan. Kepemilikan manajer yang cenderung besar menyebabkan perusahaan cenderung memilih tambahan hutang dari pada menambah saham supaya kepemilikannya tidak terlikuidasi. Hal ini terjadi karena control yang besar dari pihak manajer mereka mampu melakukan investasi dengan lebih baik sehingga memerlukan tambahan dana melalui hutang untuk pendanaan perusahaan (supply hypothesis).

\subsubsection{Pengaruh Institutional Investor terhadap kebijakan Hutang (Hipotesis 2)}

Dari hasil pengujian dengan SPSS secara parsial sebagaimana dalam table uji $t$ di atas nilai signifikansi variable Institutional Investor (INST) terhadap kebijakan Hutang (DR) sebesar 0.426 lebih besar dari nilai $\alpha=5 \%$ maka Hipotesis 2 ditolak. Sehingga dapat disimpulkan variable Institutional Investor tidak berpengaruh siknifikan terhadap kebijakan hutang perusahaan di Indonesia.

Tidak siknifikannya pengaruh institutional investor terhadap kebijakan hutang (debt ratio) kemungkinan kurang aktifnya usaha para pemegang saham besar perusahaaperusahaan di Indonesia untuk menggunakan kekuasaannya untuk melakukan monitoring manajer dalam menggunakan hutang. Hal tersebut disebabkan keyakinan mereka bahwa kinerja perusahaan di Indonesia masih dalam tingkatan yang aman "wajar", karena rata-rata tingkat hutang (debt ratio) yang digunakan dalam pendanaan perusahaan-perusahaan di Indonesia masih kecil sekitar 27, 58\% dari total pendanaan yang dilakukan baik berasal pendanaan internal maupun pendanaan eksternal.

\subsubsection{Pengaruh Shareholder Dispesion terhadap kebijakan Hutang (Hipotesis 3)}

Dari hasil pengujian dengan SPSS secara parsial sebagaimana dalam table uji t di atas nilai signifikansi variable Shareholder Dispersion (SDR) terhadap kebijakan Hutang (DR) sebesar 0.239 lebih besar dari nilai $\alpha=5 \%$ maka Hipotesis 3 ditolak. Sehingga dapat disimpulkan variable Shareholder Dispesion tidak berpengaruh siknifikan terhadap kebijakan hutang perusahaan di Indonesia.

Tidak siknifikannya variable shareholder dispersion terhadap kebijakan hutang, kemungkinan disebabkan persebaran kepemilikan saham perusahaan-perusahaan di Indonesia tergolong terkonsentrasi dan kepemilikan saham rata-rata dimiliki oleh 4-8 shareholder (tidak menyebar) dan mayoritas adalah kepemilikan saham dipegang oleh pihak institusi yaitu sebesar 53,36\% dan insider sebesar 7.22\%. ketika kepemilikan saham terkonsentrasi (hanya ada beberapa pemilik) biasanya berbasis keluarga, dimana pemilik utama bertindak sebagai manajer dalam perusahaan tersebut, menyebabkan manajer tersebut cenderung bebas dan sulit dikontrol dalam kebijakan pendanaannya (menggunakan hutang). 


\section{KESIMPULAN}

Hasil penelitian menunjukkan bahwa tidak semua struktur kepemilikan mempunyai pengaruh terhadap kebijakan hutang perusahaan-perusahaan di Indonesia. Dari tiga variable struktur kepemilikan insider ownership, institutional investor, dan shareholder dispersion, hanya variable insider ownership sajalah yang memiliki pengaruh positif yang siknifikan terhadap kebijakan hutang hutang perusahaan di Indonesia. Sedangkan variable institutional investor dan shareholder dispersion tidak memiliki pengaruh yang siknifikan terhadap kebijakan hutang perusahan-perusahan di Indonesia.

Penelitian ini masih banyak keterbatasan, sehingga disarankan penelitian-penelitian di masa yang akan dating yang ingin melihat bagaimanakah pengaruh struktur kepemilikan terhadap kebijak hutang perusahaan-perusahaan di Indonesia, menggunakan variable lain sebagai pertimbangan factor interpersonal diri manajer seperti: tingkat pertanggungjawaban manajer terhadap resiko (risk beating), loyalitas manajemen terhadap perusahaan dll. Perlu juga untuk menggunakan factor-faktor internal dan eksternal perusahaan yang lain sebagai variable independen tambahan.

\section{DAFTAR PUSTAKA}

Agus Sartono, Kepemilikan orang Dalam (Insider Ownership), Utang dan Kebijakan Deviden: Pengujian Empirik Teori Agensi (Agency Theori), 1999, Jurnal Siasat Bisnis No. 6 Vol. 2.

Arifin Zaenal, Teori Keuangan dan Pasar Modal, Ekonisia, 2005, Yogyakarta.

Easterbrook, F. Two Agency Cost Explanations of Dividend, The American Economics Vol. 74, No. 4 (Sep., 1984), 650-659, 1984.

Faisal, Pengaruh Struktur Kepemilikan Terhadap Kebijakan Hutang Pada Perusahan Manufaktur di BEJ, Thesis Program Pascasarjana Magister Saint Fakultas Ekonomi UGM, 200, Yogyakarta.

Fama, E., Agency Problem and the Theory on the Firm, Journal of Political Economy Vol. 88, 288-325, 1980.

Friend, I.and J. Hasbrouk, Determinants of Capital Structure, Research in Finance Vol.7, 19., 1988.

Hidayat, Analisis Pengaruh Struktutr Kepemilikan, Faktor Internal Perusahaan, dan Faktor Eksternal Perusahaan Terhadap Kebijakan Hutang pada Perusahaan yang terdaftar di BEJ, Skripsi Fakultas Ekonomi UII, 2004, Yogyakarta.

Ismiyati Fitria, Mahmud M, M. Hanafi, Kepemilikan Manajerial, Kepemilikan Institutional, Kebijakan Hutang dan Kebijakan Deviden: Analisis Persamaan Silmutan, Simposium Nasional Akutansi VI, 2003, Surabaya. Indonesian Capital Market Direktory Elevent Edition, 2003 Indonesian Capital Market Direktory Elevent Edition, 2004 Indonesian Capital Market Direktory Elevent Edition, 2005 Indonesian Capital Market Direktory Elevent Edition, 2006 Indonesian Capital Market Direktory Elevent Edition, 2007

Jensen M.C \& Meckling W.H, Theory Of The Firm: Manajerial Behavior, Agency Costs, And Ownership Struktur, Journal Of Financial Economics 3 (1976) 305-360, North-Hollan Publishing Company, Rochester NY14267 U.S.A., 1976.

Jensen M.C, Agency Cost of Free Cash Flow, Corporate Finance, and Takeovers, American Economics Review Vol. 76, 323-329., 1986

Kim, W. and E. Sorensen, Evidence on the Impact of the Agency Costs of the Debt on Corporate Debt Policy, Journal of Financial and Quantitative Analysis vol. 21, no. 2, 
(Juni 1986), 131-144, School of Business Administration, University of Washington, 1986, http://dx.doi.org/10.2307/2330733

Mohd, M.A., L.G. Perry., and J.N.Rimbey. (1988), The Impact Ownership Structure on orporate Debt Policy: A Time-Series CrossSectional Analysis, Financial Review, College of Business Administration, University of Arkansas, August, Vol.33, 85-89 http://dx.doi.org/10.1111/j.1540-6288.1998.tb01384.x

Manne Herry G, Merger and Market For Corporite Control, The Journal of Political Economy, Vol. 73, No. 2. (Apr., 1965), pp. 110-120, The University of Chicago Press, 1965, http://www.jstor.org/stable/1829527

Nisa Fidayati, Faktor-Faktor Yang Mempengaruhi Kebijakan Hutang Perusahaan, Jurnal Manajemen dan Akutansi, 2001, Yogyakarta.

Peter M. Bergavin, Financial Statmen Analisis, Pearson Education Financial, Inc.

Santoso Singgih, Mengolah Data Statistik Secara Personal Dengan Program SPSS Versi 10.0, Elex Media Computindo, Jakarta, 2001.

Shleifer A. \& Vishny R.W., Large Shelholders and Corporite Control, Jurnal Of Politic Economy Volume 94 Issue 3 Part 1 (Juni 1986) 461-488, The University Of Chicago Press, 1986.

Tarjo, Jogiyanto, Analisis Free Cash Flow dan Kepemilikan Manajerial Terhadap Kebijakan Hutang Pada Perusahaan Publik di Indonesia, Simposium Nasioanal Akutansi, 2003

Warsidi, Teori Akutansi, www.Warsidi Akuntan Tripo.com

Wuryaningsih, Pengujian Pengaruh Capital Struktur Pada Debt Ratio (Studi Empiris Perusahaan Manufaktur di Indonesia, Jurnal Manajemen dan Siasat Bisnis, Vol. 8 No. 2, 2004. 